\title{
Determinants of Geographical Representation on Candidate Lists in Flexible-List Systems: Lessons from the Belgian Case
}

\section{Gert-Jan Put}

Accepted for publication in Politics

\section{Introduction}

The focus of this paper is on the geographical representativeness of party lists. It examines which party- and electoral system-related attributes explain the variation in that response variable. By doing so, this contribution seeks to improve our understanding of the geographical dynamics of intraparty candidate selection processes.

Electoral systems are often evaluated on the basis of their ability to translate election results into legislatures that reflect the composition of society. In proportional systems, we expect vote shares to be accurately translated into seat shares. In addition, members of parliament should also be a representative sample of society, for instance in terms of gender, ethnicity, age and geography. This argument stems from the theory of descriptive representation, which posits that a political institution must mirror the image of society to be viewed as legitimate by all segments of society (Pitkin, 1967; Birch, 1993).

Of the personal traits mentioned in the previous paragraph, the geography of MPs and candidates is definitely one of the under-researched topics. By contrast, scholars have extensively studied the representation of women and ethnic minorities in parliaments (Htun, 2004; Norris, 2004). Moreover, it has been well-documented why parties in proportional systems are inclined to balance their ticket to include women and ethnic minority groups among their candidates (Matland, 1993).

With regard to the geographical background of MPs and candidates, we know that the large majority of electoral systems work with electoral districts to ensure geographical representation in parliament. But even electoral systems with a single national constituency produce geographically representative parliaments (Latner and McGann, 2005). While it was clear that political parties played an important role in realizing geographical representation within the nationwide districts, it has not been examined how they achieved that result. Some authors claim that their internal candidate selection methods recognize the importance of 
regionalism, and force party selectorates to produce geographically representative party lists (Koole and Leijenaar, 1988; Hazan, 1997).

This paper attempts to shed more light on the determinants of geographical representation on party lists and within districts. The question I try to tackle, is the following: which electoral system-related and party-related variables influence this outcome at the district (i.e. party list) level? A dataset was built on the place of residence of candidates on 488 party lists for seven elections of the Belgian Lower House (1987-2010). Two measures of geographical representation at the party list level will be used as outcome variables in the empirical analysis.

Belgium is a case where geography is strongly embedded in the political culture: it is a federal system combining territorial and non-territorial substate levels, with separate party systems and strong regional identities. Therefore, it is an interesting case to analyze geographical dynamics of candidate selection processes. In addition, recent electoral reforms have significantly increased district magnitude and the level of gender representation through the introduction of quota laws, creating variation in key independent variables mentioned in the literature.

\section{A general theory of ticket-balancing}

Ticket-balancing implies that parties present a balanced group of candidates in terms of their background characteristics. With regard to the geographical background of candidates, this means that party selectorates nominate candidates living in various areas in the district, instead of a geographically more concentrated group. If this is indeed a primary concern for parties, the place of residence of aspirant-candidates becomes one of the candidate selection criteria.

However, a reading of the literature on the political representation of ethnic groups and women suggests that the importance of balancing tickets depends on the electoral system type and district magnitude, defined as the number of seats per district (Matland, 2005). In majoritarian systems, where district magnitude usually equals one, parties do not even have the chance to balance their ticket. They nominate only one candidate, and pursue the strategy of selecting a lowest common denominator (Tremblay, 2012), i.e. that particular candidate with the broadest electoral appeal. This maximizes the odds of winning a majority of votes and consequently the seat. In proportional systems, on the other hand, district magnitude is 
considerably higher, and parties could win multiple seats in the district. In other words, party magnitude (defined as the number of seats a party wins in the district) increases, which implies that parties are able to divide their winning slots or realistic list positions among candidates from various social groups.

Parties in proportional systems thus have the theoretical possibility to balance their ticket, and will be inclined to do so for both electoral and organisational reasons (Gallagher and Marsh, 1988; Norris, 2004; Valdini, 2012). From the electoral perspective, the exclusion of any major social group could signal discrimination, which could result into an electoral penalty at the ballot box (Norris, 2006). The ticket-balancing strategy also makes sense from a party cohesion perspective: balancing the slate avoids internal conflict between party factions (Norris, 1997).

The ticket-balancing process is often considered a crucial factor affecting women's presence in parliaments and on party lists (Matland and Studlar, 1996). But the exact nature of this process, and the actual number of women getting elected, depends on the configuration of three elements: ballot structure, district and party magnitude. First, ballot structure determines which part of the candidate list should be balanced to guarantee the election of women candidates. In closed list systems, where the specific rank order of candidates on the list determines who gets elected, parties have to put women in one of the top positions on the list (Marsh, 2005). In open list proportional systems, only the voters decide who will get elected by casting preference votes for one or more candidates on the list. In this case, the specific position of women candidates on the list is less important (see, however: Miller and Krosnick, 1988). Finally, in the more hybrid list PR systems where both rank order and preference votes come into play (e.g. flexible list systems), it is important to have female candidates in winning slots as well as on the list in its entirety.

Second, the higher the district magnitude, the higher the absolute number of list slots and thus the available space to present a balanced group of candidates (Carey and Shugart, 1995; see, however: Crisp, Jensen, and Shomer, 2007). This positive association between district magnitude and list positions is a crucial element in the ticket-balancing mechanism: a long list of candidates allows parties to include all relevant social groups on the ballot (Lovenduski and Norris, 1993; Norris, 1997). Consequently, any type of research on the relation between district magnitude and geographical representation should take into account the number of list slots. The third and final element, party magnitude, determines whether these groups have a 
realistic chance of getting elected to parliament. If a party expects to win only one seat in the district, the candidate selection process becomes a winner takes all event, thereby making ticket-balancing purely cosmetic (Young, 1994).

While this discussion of the ticket-balancing process largely focuses on gender representation, I argue that the same mechanisms work for geographical representation. Higher district and party magnitude increases the chances of seeing candidates living in both urbanized and rural areas on the party list and elected to parliament.

But even in the most ideal institutional setup, there is no absolute guarantee that parties will actually balance their ticket. In fact, some parties might still prefer to nominate a very homogenous group of candidates, without actually getting electorally punished or creating intraparty turmoil. If those parties' electoral support is largely concentrated, they will be less inclined to balance the ticket. Ethnic parties, for example, will mainly draw candidates from their own ethnic minority group since they are not interested in drawing support from other social groups (Holmsten, Moser, and Slosar, 2010).

Applying this argument to geographical representation means that parties with geographically concentrated support will be less likely to produce geographically balanced tickets. Parties with geographically dispersed support, however, will put some effort in selecting candidates from various areas. In the next section, I derive a number of independent variables from the literature, and discuss their expected effects on the level of geographical representation on party lists.

\section{Independent variables and hypotheses}

District magnitude has already been discussed as an important predictor for the level of representation in parliaments and on party lists. In general, district magnitude is positively correlated with both the number of list slots and party magnitude, which means that both list space and multiple winning slots are available to get candidates from various social groups elected to parliament. The literature states that minority groups will have higher levels of political representation in larger districts (Matland, 1993).

In terms of geographical representation, this would imply that district magnitude has a positive effect on the representation of geographic minority groups. I argue that candidates from small municipalities perform the minority role. In general, party selectorates will be more inclined to nominate candidates from the larger and middle-sized municipalities of the 
district: those candidates share their place of residence with a larger proportion of voters which makes them electorally more attractive, and they resort on more resourceful grassroots organizations than candidates from the smallest municipalities. But this latter group does stand a chance of getting nominated in the largest districts: as district magnitude (DM) increases, the number of list positions increases as well, and parties will be more willing to allocate list slots to geographical minority groups. This leads to the first hypothesis of this paper:

H1. An increase in DM leads to higher levels of geographical representation on party lists. As mentioned earlier, even electoral systems with favorable conditions for balanced tickets will have parties with no interest in ticket-balancing efforts. Recent research shows that there is not only strong variation in the importance attached to descriptive representation, but also in terms of the prioritized social dimension, for which there seems to be a left-right divide (Caramani, Celis, and Wauters, 2014). Arguably, one could measure party efforts by using one form of social group representation as predictor of another form. Put differently, if a party list scores high in terms of the representation of women, it could be expected that they also perform better in terms of geographical representation.

This argument stems from a strong claim in the literature that various forms of social group representation are positively associated (Taagepera, 1994; Lijphart, 1999). The idea is that the same factors contribute to higher levels of gender and ethnic representation, mainly the electoral system in place, candidate supply and cultural factors (Dahlerup, 2013). While these authors focus on parliamentary representation, this association might also hold true for party lists. Controlling for electoral system type and district magnitude, the level of gender representation might be positively associated with geographical representation. In other words, if party selectorates invest in representational politics and find it important to reflect society on party lists, geographical representation will go hand in hand with the presence of women candidates:

H2a. The levels of gender and geographical representation on party lists are positively associated.

There has not been a lot of convincing empirical evidence for this argument. Based on a dataset comprising 95 countries, Ruedin (2010) found no positive association between levels of gender and ethnic group representation. However, the author did not find a negative 
correlation either, indicating that it is not the case that increasing levels of representation in one form might come at the cost of another. One could, however, make the argument that it does: strong fixation on the representation of one social group may impede the representation of other groups. The literature points to possible tensions between gender and minority group representation (Holmsten, Moser, and Slosar, 2010; Rahat and Malka, 2012). As a result, an alternative hypothesis is formulated:

$\mathrm{H} 2 \mathrm{~b}$. The levels of gender and geographical representation on party lists are negatively associated.

Another relevant covariate is the nature of the parties' candidate selection methods. The most useful analytical framework for comparative analysis of candidate selection methods has been developed by Hazan and Rahat $(2001 ; 2010)$. Their model disentangles four dimensions of candidate selection, among which selectorate and decentralization are the most important. The selectorate, on the one hand, is the body that selects the candidates, and can be composed of only one person, or several people, up to the entire electorate. This dimension can be measured on a continuum from exclusive selectorates, where a very limited group of selectors take control, to inclusive selectorates, such as party members or the electorate. Decentralization, on the other hand, measures the influence of local party branches in candidate selection. In the most centralized methods, the national party level has complete control over the nomination process.

There has been some research attention to the effects of candidate selection methods on political representation (Hazan and Rahat, 2010). Spies and Kaiser (2014) find that the representativeness of parties towards their voters in terms of left-right position is lower in candidate selection methods with more inclusive selectorates. Another interesting result is that parties with highly inclusive candidate selection methods produce lists with lower levels of demographic representation. Rahat, Hazan, and Katz (2008) find that selection methods with membership ballots are less likely to produce candidate lists with women on safe positions. Highly exclusive methods, on the contrary, lead to highly representative sets of candidates.

The underlying reason is the difference in the fundamental nature of the task confronting selectors in membership ballots vis-à-vis exclusive party committees. In membership ballots, on the one hand, members are asked after their individual preferences about party candidates. Selectors in party committees, on the other hand, are more inclined to base their decision on an evaluation of the collective good of the party. In addition, membership ballots will also 
lead to unbalanced candidate lists because the actions of such a vast selectorate are more difficult to coordinate than the actions of party committees with a limited number of selectors. Following this argument, I formulate the following hypothesis:

H3. Exclusive candidate selection methods lead to higher levels of geographical representation on party lists.

The link between decentralization of candidate selection methods and the level of geographical representation on candidate lists seems more straightforward. According to Hazan and Rahat (2010), this relationship is positive because 'if more power in the candidate selection process is given to the regional and/or the local selectorates, at the expense of the national party organization, the likely result will be more candidates chosen who represent the regional and local levels.' In other words, it is argued that candidates selected by a decentralized, regional or local selectorate, will be more geographically representative than candidates selected by national party selectorates.

H4. Decentralized candidate selection methods lead to higher levels of geographical representation on party lists.

\section{The case of Belgium}

The Belgian electoral system is often characterized as a flexible list system, where voters are able to endorse the party list as a whole or to cast one or multiple preference votes for party candidates on the same list (Shugart, 2005). In theory, both list order and the number of preference votes play an important role in intraparty seat allocation. In practice, however, the threshold of preference votes to overcome the list order is reached very infrequently, which led scholars to characterize flexible list systems as closed-list systems in disguise (Crisp, et al., 2013). In recent years, the Belgian system has experienced a number of important electoral reforms that created variation in the key independent variables examined in this paper.

First, district magnitude has increased substantially over the last two decades. As part of the fourth Belgian state reform in 1993, the number of electoral districts decreased from 30 to 20 . This was a consequence of the decision to reduce the number of seats in the lower House from 212 to 150 . As a result of these reforms, the average district magnitude increased from 5 to 7.5. As part of a second electoral district reform in 2002, the number of districts decreased a 
second time from 20 to 11 . Table 1 presents a number of descriptive statistics on the evolution of district magnitude for the election of the Belgian lower House.

< Table 1 about here >

The table shows that the Belgian case is a good example of the positive, but not completely linear association between district magnitude and the number of list positions (Crisp, Jensen and Shomer, 2007). The introduction of larger districts clearly led to higher numbers of list positions. To some extent, this gave parties additional space to keep nominating candidates from both large and small municipalities. However, this should not be exaggerated: in both reforms the increase in the average list length was lower than the increase in the average district magnitude. In 1992, the average district magnitude increased by a ratio of $1.5(7.5 / 5)$ and the average list length by a ratio of 1.1 (13.3/12.2). As a result, the net effect would still be a decrease in the number of candidates per seat. ${ }^{1}$ Figure 1 visualizes these reforms.

\section{< Figure 1 about here >}

In some Belgian parties, local party branches feared that these electoral reforms would make it more difficult for small municipality candidates to gain campaign visibility (Pilet, 2007). As elections would be organized on a higher scale in enlarged districts, the candidates from the largest cities of these districts would dominate election campaigns. This argument is at odds with the theoretical claim that district magnitude is in fact positively associated with political representation.

A second relevant electoral reform in Belgium was the introduction of candidate gender quotas. The first Belgian quota law was introduced in 1994 and first applied in the 1999 elections. It stated that no more than two thirds of the candidates on party lists could be of the same sex. In 2002, this law was adapted in the sense that party lists should from then on include an equal number of male and female candidates. In addition, at least one of the top three positions on the party list should be reserved for women. Right before the election of 2007 , this was again adapted to at least one woman in the two top positions.

After the introduction of candidate gender quotas, all Belgian parties were legally bound to nominate a sufficient number of women candidates on their party lists, and afterwards even in the winning slots. This substantially increased both the number of women candidates on realistic list positions and the number of female MPs in the Lower House (from 7.7\% in 1987 to $38.5 \%$ in 2010 ). 
Third, Belgian candidate selection methods have varied considerably over the last decades. Various Belgian parties have employed highly inclusive selection methods over the last decades, allowing their members to participate in the process. The Flemish and Walloon Christian-Democrats, for example, have frequently been using a system of member polls: party members had the possibility to ratify or reject a model list drafted earlier by more exclusive party agencies (De Winter, 1988). Furthermore, the Flemish liberals introduced a highly inclusive system of primaries in the 1990s, which gave the opportunity to registered voters to nominate candidates for parliamentary elections (Verleden, 2013).

Other parties used methods that involved party delegates. Since they are appointed by the members, these delegates can be seen as an indirect inclusion of party members in the selection process. The Flemish Socialists, for example, applied selection methods where the lists were ratified by an assembly of member delegates. But also the Flemish ChristianDemocrats used these assemblies for the first three elections included in the analysis (Deschouwer, 1993).

Finally, there are also examples of highly exclusive selection methods, where no members or member delegates are involved in any way. The Walloon liberal party MR is a good example of this category: only the presidents of the various party components were entitled to appoint the most important candidates on the party lists, and in a final step approve the entire candidate lists (Vandeleene, et al., 2013).

But also in terms of centralization, there was considerable variation among Belgian parties between 1987 and 2010. The Flemish liberal party, for example, has a strong tradition of keeping the role of the national party level very limited. In other cases, candidate lists are the result of an interaction between party agencies at the district and national party level. A typical example are the selection methods applied by the Flemish Christian-Democrats: after a party agency at the district level took the initiative of drafting a first list proposal, a national party agency could either modify or ratify this list, before it was presented to the members through a poll.

Centralization was highest where the national party level had veto right in the final step of the selection process. In 2003 and 2007, the Walloon Christian-Democrats organized a candidate selection procedure where a national party committee with a limited number of members could approve the model list drafted by the district organization, or simply overrule the decisions made at the district level and draft a completely different proposal. 


\section{Data, measurements and method}

I constructed a dataset on the place of residence of Belgian party candidates for all the elections of the Lower House since $1987 .{ }^{2}$ These data on candidates from 488 party lists was used to calculate the level of geographical representation on the lists. The dataset contains information on candidates from eight Belgian parties: the Christian-democrats, liberals, socialists and green parties of the Walloon and Flemish regions of Belgium. The criterion for selecting these parties was their level of institutionalization and whether they have been represented continually in parliament. ${ }^{3}$

One of the key issues to deal with is of course how to measure the level of geographical representation on party lists. I consider a party list to be geographically representative when it includes candidates from the highest possible number of municipalities. This will be measured by means of municipality-indicator $M i$ :

$$
M i=\frac{N_{r}}{N_{t}}
$$

where $N_{r}$ is the number of municipalities represented on the party list, and $N_{t}$ is the total number of municipalities in the district. In other words, this indicator calculates the proportion of municipalities represented on the party lists. The higher the score, the higher the territorial coverage of the district in terms of party candidates.

This measure of geographical representation does not take into account list positions. Rank order remains an important determinant of the candidate's odds of getting elected in the Belgian flexible list system. There might be substantial differences between the level of geographical representation on the party list in its entirety on the one hand, and the realistic positions on the other. As a result, a second indicator focuses on the realistic list slots. More specifically, it measures the proportion of candidates of the largest municipality on the realistic list slots:

$$
R_{i}=1-\frac{R_{l m}}{R_{n}}
$$

Where $R_{l m}$ is the number of candidates of the largest municipality on a realistic place, and $R_{n}$ is the total number of realistic places on the party list. In other words, this indicator focuses on the dominance of large city candidates: the higher the proportion of large city candidates in realistic slots, the lower the geographical representativeness of the list. I take the inverse of 
this proportion for reasons of interpretation: higher proportions of large city candidates decreases the representativeness and the value of this indicator.

In practice, Belgian party selectorates distinguish between realistic and non-realistic positions on the list, using previous election results as benchmarks (Put and Maddens, 2013). For example, if a party won three seats in a district during the previous election, the first four positions could be considered realistic: the candidate on the fourth positions stands a real chance of being elected on the condition that his or her number of preference votes is high enough and/or the party realizes a significant upward swing in the district. In addition, the Belgian case has known many examples of the candidate at the bottom of the list managing to get elected instead of a higher ranked candidate (Wauters, Weekers, and Pilet, 2004). This is so because parties often choose popular politicians for this final position. For these reasons, the 'list pusher' will also be considered a realistic position in the analysis. Finally, the first substitute candidate is also included in the category of realistic list positions, since this is a list slot with a realistic possibility of getting a seat in the event of resignation, death or a ministerial office for one of the other elected MPs on the list.

These two indicators both focus on the municipality level as the relevant geographical unit, and this for two substantial reasons. First, the municipality level is the lowest organizational unit within Belgian political parties and could still be seen as building stones of their party organizations (Deschouwer and Rihoux, 2008). They perform the crucial task of recruiting talented aspirant-candidates. Second, politicians' local ties are usually perceived in terms of previous political experience at the municipal level (Tavits, 2010; Put and Maddens, 2014).

District magnitude (DM) is measured by the number of seats per district. In the multivariate analyses, I use the logarithm of DM to control for the influence of outliers, since the natural $\mathrm{DM}$ in the dataset ranges from 2 to 24 . I will also control for the average number of list slots per municipality, which is a relative measure of the number of list positions. This variable summarizes the scarcity of list slots compared to the number of municipalities in the district, and expresses the level of competition among the various municipalities in the district to get at least one list slot.

The level of gender representation on party lists is measured by the proportion of female candidates in realistic list slots. As a result of the introduction of quota laws, this proportion will generally increase over the seven Lower House elections under investigation. However, by using this measure, I control for substantial differences between party lists within 
elections. For example, while parties were not legally required to nominate $50 \%$ of female candidates before 2003, the Flemish green party already reached this threshold in 1995 (Maddens et al., 2014).

To estimate the effect of intraparty candidate selection methods, I work with selection indexes measuring the dimensions of selectorate and decentralization on an ordinal scale. While earlier studies have used integrated 6-point and 8-point scales amalgamating these two dimensions (Shomer, 2009; Shomer, 2014), I use two separate scales to test the distinct effects of inclusiveness and decentralization on the response variables. Data on Belgian candidate selection methods were collected on the basis of party regulations, interviews with party officials, news articles and existing literature on the topic.

< Figure 2 about here >

The level of inclusiveness of Belgian candidate selection methods is measured on a 3-point scale. The highest level on this scale are selection methods where members are directly involved, for example by ratifying the model lists that have been drafted by one of the party agencies. The middle category on this scale are the selection methods where party members appoint delegates. The most exclusive category are procedures where members or delegates are not involved in any way, but one or more non-selected party agencies dominate the selection process.

\section{$<$ Figure 3 about here >}

I constructed a similar 3-point scale for measuring the level of decentralization. The highest score on the scale is for selection methods where the constituency organization has full autonomy in drafting the list. If, however, the selection process takes the form of an interaction between the national and district level, the observation fits the second category on the index. The most centralized procedure is when the national party level controls the final step of the selection process and/or has the chance to overrule any previous decisions taken at a lower party level.

Finally, two control variables will be added to the analysis: the relative number of realistic slots on the party list, and the relative size of the largest city in the district. A large number of realistic list positions increases the available space on the list to balance the ticket, and should be taken into account. The second control variable is especially important when modelling $R i$ : 
self-evidently, the larger the largest city in the district, the more realistic slots will be assigned to candidates from that city.

Finally, both dependent variables $M i$ and $R_{i}$ are proportions, which means that both the assumptions of continuous scores and normality are violated. The classical solution to this problem is to perform a logit transformation to achieve normality, followed by OLS regression. The following transformation is applied: ${ }^{4}$

$$
\operatorname{Logit}(R i)=\ln \left(\frac{R i}{1-R i}\right)
$$

In addition, there are several reasons to believe that the 488 party lists in the dataset are not independent observations. First, these are party lists from seven subsequent elections, creating the possibility that there might be a time effect involved which is not measured by other independent variables. Second, the eight political parties included in the dataset belong to four different ideological families. As mentioned in the theoretical discussion, party ideology might play an important role in determining what type of representation is prioritized on the party list. As a result, to avoid omitted variable bias in the multivariate analysis, I add fixedeffects for elections and party family to the models.

\section{Results}

What determines geographical representation on party lists? Table 2 first summarizes some descriptive statistics on the dependent and independent variables included in the analyses. The results indicate that, on average, $43 \%$ of the municipalities in a district are represented on party lists. With regard to the second dependent variable, the large city candidates get on average $28 \%$ of the realistic list positions. Put differently, $72 \%$ of these positions are allotted to other municipalities than the largest city in the district. Another interesting finding is that only $24 \%$ of the realistic list slots were assigned to women candidates on the average party list. In sum, these descriptive results suggest that Belgian parties do realize geographical representation on party lists. We now move to the multivariate models to examine which party- and electoral system-related mechanisms are at work to ensure this within district representation levels.

\section{$<$ Table 2 about here >}

In the remainder of this section, I discuss the results of two fixed effects regression models with $M i$ and $R_{i}$ as dependent variables. ${ }^{5}$ Table 2 presents the coefficients of these two models. 
Model 1 regresses the first indicator $M i$ on the independent variables mentioned in Table 2. Concerning candidate selection methods, especially decentralization plays a substantial role in explaining variation in the level of territorial coverage on party lists. Highly decentralized methods, where candidate selection takes place at the district level without any national interference, lead to the highest levels of geographical representation. Both the second and third category on the decentralization scale have significantly lower proportions of municipalities on the candidate list, which is in line with the fourth hypothesis. The results with regard to inclusiveness of the selectorate are not that straightforward: the middle category, which involves influence of member delegates in candidate selection, yields the highest scores on this indicator. The data does not show a clear pattern for the effect of this second candidate selection dimension.

It is clear that the effects of the selectorate and decentralization on the level of geographical representation are substantially different. The decentralization dimension seems to play the most important role: if parties choose candidate selection methods with influential local party branches, then small municipality candidates will get nominated and large city candidates will be less dominant. Furthermore, the finding that partially inclusive selection methods with party delegates lead to more geographical representation seems to be at odds with earlier research (Rahat, Hazan, and Katz, 2008). On the contrary, it confirms the alternative argument developed by Kernell (2008) that inclusive selectorates in fact lead to higher levels of responsiveness and representation. A high number of selectors means that a large variety of interests are represented in candidate selection, which increases the chance that representational issues are taken into account when selecting candidates.

\section{$<$ Table 3 about here >}

As expected, the average number of list slots per municipality has a highly significant positive effect on the territorial coverage on party lists. This is a rather straightforward and mechanical effect: the more space available on the party list for candidates, the more municipalities in the district will have at least one candidate on that list. In addition, the population proportion of the largest city in the district has a negative effect on the first indicator of geographical representation. This implies that in districts where the largest city is demographically dominant, there will be a lower proportion of municipalities represented on party lists. Moving on to the fixed-effects coefficients, it is interesting to see that socialist and green 
parties have comparatively lower levels of geographical representation than their liberal and Christian-democratic counterparts.

Model 2 explains variation in the second indicator $R_{i}$, which focuses on the dominance of the largest city on realistic list slots. First, the percentage of women candidates in realistic list slots seems to be negatively correlated with this indicator. In other words, high levels of gender representation lead to higher dominance of large city candidates and consequently lower levels of geographical representation in realistic slots. This is in line with H2b, the more pessimistic interpretation of the association between different forms of social group representation.

Second, the highly significant effect of the percentage realistic list slots is again very logical: if a list has a high number of interesting or eligible list positions, there is more space available to allot these positions to candidates from other municipalities than the largest city in the district. Third, and analogous to the first model, the population proportion of the largest city has a negative impact on the second indicator of geographical representation, which is again straightforward. Parties seem to reason that cities which dominate the electoral district in terms of population size should dominate the best places on the candidate lists as well. Fourth and finally, with regard to the fixed-effects, the results are similar to the first analysis. More specifically, socialist and green party lists again score significantly lower on the second indicator. ${ }^{6}$

None of the models provide support for the first hypothesis, which stated that increased district magnitude itself leads to higher levels of geographical representation. Even when the list positions variable is removed from the model, there is no significant effect. Again, this finding runs counter with the conventional wisdom in the literature that minority groups have higher levels of political representation in larger districts. For geographical representation on party lists, district magnitude plays a limited role.

\section{Conclusion}

The aim of this paper was to provide more insight into the dynamics of geographical representation on party lists. Based on the relevant literature, I selected a number of independent variables which were expected to have an impact on geographical representation on the candidate lists of eight Belgian political parties. 
Some of the results were not particularly surprising. For example, the fact that higher numbers of list slots per municipality increases the territorial coverage of party lists is self-evident. The same holds for the second analysis, where I found that a higher number of realistic list slots leads to a higher level of geographical representation in those positions. In sum, the more space is provided on candidate lists, the more parties will take into account geographical balance on their list.

However, if the number of list slots is limited, parties face tough choices in candidate selection processes. The results suggest that selectorates are less inclined to geographically balance the ticket if the largest city in the district is relatively dominant in terms of population size. Local party branches are able to prevent this if they have any form of influence in candidate selection processes: the data suggest that highly decentralized candidate selection methods lead to party lists with higher levels of geographical representation. This is an important finding, as it confirms that 'territorial decentralization has a positive relationship with territorial representation' (Hazan and Rahat, 2010, p. 118). More specifically, locally organized candidate selection guarantees that candidates from both urban and rural areas are represented on party lists. This means that parties can counterbalance nationalization and centralization tendencies as a result of, for example, electoral reforms by decentralizing their candidate selection methods.

Until now, the literature mainly focused on the effects of selectorate on candidate list representation. The more dominant theory is that exclusive selectorates produce party lists with higher levels of representation, since they are inclined to think more in terms of the common good than inclusive selectorates (Rahat, Hazan, and Katz, 2008; Hazan and Rahat, 2010). The results do not support this claim, and instead show that the moderately inclusive category of party delegates render lists with higher geographical representation. In other words, this finding is in line with the competing claim by Kernell (2008) that inclusive selectorates are producing party lists with higher levels of representation.

In any case, there is need for more empirical research on the effects of candidate selection methods on party list representation, both in terms of the geographical dimension and other demographic candidate characteristics. Moreover, this empirical exercise has proven that selectorate and decentralization should be treated as two separate independent variables, not only because they are separate analytical dimensions that measure different things, but also because they have differential effects on party list representation. Amalgamating these two 
dimensions in one integrated scale limits our insight into the mechanisms and consequences of intraparty candidate selection.

In addition, the results for the realistic slots support the hypothesis about negative associations between different forms of social group representation. More specifically, high percentages of women in realistic slots go hand in hand with high numbers of large city candidates, and consequently lower levels of geographical representation. Parties that recruit large numbers of women for the highest list positions are also inclined to select more candidates from the largest city within the district.

Can these results be generalized, both to other candidate characteristics and to other country cases? At the beginning of the paper, I argued that the ticket-balancing dynamics work similarly for different types of social representation. To a certain extent, this is true: the available list space and party magnitude, operationalized as the percentage of realistic list slots, strongly determine geographical representation levels. This confirms that comparable mechanisms are at work. However, there are also important differences between the geographical dimension and other criteria, such as gender, ethnicity and age representation. Geography is the only one of these dimensions that is institutionalized in party structures in the form of regional and local party branches. Put differently, organizational incentives for geographical ticket-balancing might be comparatively stronger than, for example, the ethnic or gender variant. ${ }^{7}$

Finally, while Belgium is of course a case with notoriously complex territorial and electoral dynamics, I believe that the results of these analyses can, to a certain extent, be generalized to comparable flexible list systems. More specifically, the variation in district magnitude and candidate selection methods of Belgian parties has been quite substantial over the last 25 years. This makes Belgium the ideal empirical testing ground for some of the hypotheses concerning the effects of electoral system and party attributes on party list representation. However, it is generally accepted in the literature that candidate selection dynamics and the effects of district magnitude on party- and candidate behavior strongly differ according to electoral system type. This creates the need for a more comparative approach in future research, including cases from closed and open list systems.

\section{Acknowledgements}


The author would like to thank the Research Foundation Flanders and the Junior Mobility Programme of the Flemish Government for their generous support. Furthermore, the author would also like to express appreciation for the comments received by Bart Maddens, Yael Shomer, Jef Smulders and two anonymous reviewers. An earlier version of the article was presented at the general conference of the European Political Science Association in Edinburgh, June 19-21, 2014.

\begin{abstract}
About The Author
Gert-Jan Put is a research fellow of the Research Foundation Flanders, affiliated to the Public Governance Institute at the University of Leuven. His research interests include electoral systems, candidate selection processes and political representation. E-mail: gertjan.put@soc.kuleuven.be
\end{abstract}

\title{
NOTES
}

\begin{abstract}
${ }^{1}$ This is mainly caused by the so-called substitute candidates: a particularity of the Belgian electoral system is that voters are presented with a list of effective as well as substitute candidates. These substitutes for the elected MPs are also rank ordered on the basis of their preference votes, after the distribution of list votes. If an MP becomes member of government, resigns or dies, he or she will be replaced by the first substitute.

${ }^{2}$ Candidates for the Lower House do not have to live in the electoral district where they will be running for election. In fact, if they are registered in any Belgian municipality on election day at the latest, the party selectorate can use them in any district they want.

${ }^{3}$ The only exception are the Flemish greens, who have been out of the Federal Parliament for one legislative term (2003-2007).

${ }^{4}$ However, this solution is still problematic if some of the observations in the dependent variable equal 0 or 1 . The logit transformation for these observations will yield undefined values, resulting in missing values and consequently a loss of information. To avoid this, I added some noise to the data to ensure that $0<R_{i}$ (or $\left.M i\right)<1$, and every observation will be included in the multivariate analyses:
\end{abstract}

$$
\operatorname{logit}\left(R_{i}\right)=\ln \left(\frac{R_{i}+0.01}{1-R_{i}-0.01}\right)
$$

5 The regression coefficients should be interpreted with some caution: since I used a logit transformation of $R_{i}$ and $M i$, the resulting coefficients should be interpreted on the logarithmic scale. Although it is possible to back-transform an estimated probability on the logit scale to the probability scale, it is not possible to back-transform a regression parameter estimate to the probability scale.

${ }^{6}$ I experimented with adding region as a fixed effect to both models. It did not have any substantial effect on the results: in both models, the region dummy was not significant at a 0.05 level and there are no significant changes in the $\mathrm{R}^{2}$ statistic. In addition, it did not change any of the other effects reported in the tables. 
${ }^{7}$ Of course, some parties also apply some form of social decentralization in their party organization and candidate selection methods (Hazan and Rahat, 2010). However, territorial decentralization clearly is the more common form of intraparty decentralization: almost every party will have some level of subnational party organization.

\section{References}

Birch, A. (1993) Concepts and Theories of Modern Democracy, London: Routledge.

Caramani, D., Celis, K. and Wauters, B. (2014) 'Representation of Old and New Groups, Old and New Cleavages', in K. Deschouwer and S. Depauw (eds.), Representing the People. A Survey Among Members of Statewide and Substate Parliaments, Oxford: Oxford University Press, pp. 39-65.

Carey, J. and Shugart, M. (1995) 'Incentives to Cultivate a Personal Vote: A Rank Ordering of Electoral Formulas', Electoral studies 14(4), pp. 417-439.

Crisp, B., Jensen, K. and Shomer, Y. (2007) 'Magnitude and Vote Seeking', Electoral Studies 26(4), pp. 727-734.

Crisp, B., Olivella, S., Malecki, M., and Sher, M. (2013) 'Vote-Earning Strategies in Flexible List Systems: Seats at the Price of Unity', Electoral Studies 32(4), pp. 658-669.

Dahlerup, D. (2013) Women, Quotas and Politics, London: Routledge.

Deschouwer, K. (1993) Organiseren of Bewegen? De Evolutie van de Belgische Partijstructuren sinds 1960, Brussels: VUB Press.

Deschouwer, K. and Rihoux, B. (2008) 'De Lokale Partijafdelingen van Hiërarchie naar Stratarchie', in J. Buelens, B. Rihoux and K. Deschouwer (eds.), Tussen Kiezer en Hoofdkwartier: de Lokale Partijafdelingen en Gemeenteraadsverkiezingen van 2006, Brussels: VUB Press, pp. 19-30.

De Winter, L. (1988) 'Belgium: Democracy or Oligarchy?' in M. Gallagher and M. Marsh (eds.), The Secret Garden of Politics: Candidate Selection in Comparative Perspective, London: Sage, pp. 20-46.

Gallagher, M. and Marsh, M. (eds.) (1988) The Secret Garden of Politics: Candidate Selection in Comparative Perspective, London: Sage.

Hazan, R. (1997) 'The 1996 Intra-Party Elections in Israel: Adopting Party Primaries', Electoral Studies 16(1), pp. 95-103.

Hazan, R. and Rahat, G. (2010) Democracy Within Parties: Candidate Selection Methods and Their Political Consequences, Oxford: Oxford University Press. 
Holmsten, S., Moser, R. and Slosar, M. (2010) 'Do Ethnic Parties Exclude Women?', Comparative Political Studies 43(10), pp. 1179-1201.

Htun, M. (2004) 'Is Gender Like Ethnicity? The Political Representation of Identity Groups', Perspectives on Politics 2(3), pp. 439-458.

Kernell, G. (2008) 'Political Party Organizations and Representation: Party Responsiveness, Candidate Heterogeneity and Voter Behavior in Mature Parliamentary Democracies' Unpublished PhD Thesis, Colombia University.

Koole, R. and Leijenaar, M. (1988). 'The Netherlands: the Predominance of Regionalism', in M. Gallagher and M. Marsh (eds.), The Secret Garden of Politics: Candidate Selection in Comparative Perspective, London: Sage, pp. 190-209.

Latner, M. and McGann, A. (2005) Geographical Representation under Proportional Representation: The Cases of Israel and the Netherlands. Electoral Studies 24(4), pp. 709-734.

Lijphart, A. (1999) Patterns of Democracy: Government Forms and Performance in ThirtySix Democracies, New Haven: Yale University Press.

Lovenduski, J. and Norris, P. (1993) Gender and Party Politics, London: Sage.

Maddens, B., Put, G.J., and Smulders J. (2014) Het DNA van de kandidaten, Leuven: Acco.

Matland, R. (1993) 'Institutional Variables Affecting Female Representation in National Legislatures: The Case of Norway', Journal of Politics 55(3), pp. 737-755.

Matland, R. (2005) ‘Enhancing Women’s Political Participation: Legislative Recruitment and Electoral Systems', in A. Karam (ed.), Women in Parliament: Beyond Numbers, Stockholm: IDEA, pp. 93-111.

Matland, R. and Studlar, D. (1996) 'The Contagion of Women Candidates in Single-Member District and Proportional Representation Electoral Systems: Canada and Norway', The Journal of Politics 58(3), pp. 707-733.

Miller, J. and Krosnick, J. (1998) 'The Impact of Candidate Name Order on Election Outcomes', Public Opinion Quarterly 62(3), pp. 291-330.

Norris, P. (1997) Passages to Power: Legislative Recruitment in Advanced Democracies, Cambridge: Cambridge University Press.

Norris, P. (2004) Electoral Engineering: Voting Rules and Political Behavior, Cambridge: Cambridge University Press.

Norris, P. (2006) The Impact of Electoral Reform on Women's Representation. Acta Politica 41(2), pp. 197-213.

Pitkin, H. (1967) The concept of representation, California: University of California Press. 
Put, G.J. and Maddens, B. (2013) 'The Selection of Candidates for Eligible Positions on PR Lists: The Belgian/Flemish Federal Elections 1999-2010', Journal of Elections, Public Opinion and Parties 23(1), pp. 49-65.

Put, G.J. and Maddens, B. (2014) 'The Effect of Municipality Size and Local Office on the Electoral Success of Belgian/Flemish Election Candidates: A Multilevel Analysis', Government and Opposition, published online.

Rahat, G., and Hazan, R. (2001) 'Candidate Selection Methods: an Analytical Framework', Party Politics 7(3), pp. 297-322.

Rahat, G., and Malka, R. (2012) 'Political Representation in Israel: Minority Sectors vs. Women', Representation 48(3), pp. 307-319.

Rahat, G., Hazan, R. and Katz, R. (2008) 'Democracy and Political Parties: On the Uneasy Relationships between Participation, Competition and Representation', Party Politics 14(6), pp. 663-683.

Ruedin, D. (2010) 'The Relationship Between Levels of Gender and Ethnic Group Representation', Studies in Ethnicity and Nationalism 10(1), pp. 92-106.

Shomer, Y. (2009) 'Candidate Selection Procedures, Seniority, and Vote-Seeking Behavior', Comparative Political Studies 42(7), pp. 945-970.

Shomer, Y. (2014) 'What Affects Candidate Selection Processes? A Cross-National Examination', Party Politics 20(4), pp. 533-546.

Shugart, M. (2005) 'Comparative Electoral Systems Research: The Maturation of a Field and New Challenges Ahead', in M. Gallagher and P. Mitchell (eds.), The Politics of Electoral Systems, Oxford: Oxford University Press, pp. 25-55.

Spies, D. and Kaiser, A. (2014) 'Does the Mode of Candidate Selection Affect the Representativeness of Parties? Party Politics 20(4), pp. 576-590.

Taagepera, R. (1994) 'Beating the Law of Minority Attrition', in W. Zimmerman and J. Zimmerman (eds.), Electoral Systems in Comparative Perspective: Their Impact on Women and Minorities, Westport: Greenwood Press, pp. 235-235.

Tavits, M. (2010) 'Effect of Local Ties On Electoral Success and Parliamentary Behavior: The Case of Estonia', Party Politics 16(2), pp. 215-235.

Tremblay, M. (2012) Women and Legislative Representation: Electoral Systems, Political Parties, and Sex Quotas, London: Palgrave Macmillan.

Valdini, M. (2012) 'A Deterrent to Diversity: The Conditional Effect of Electoral Rules on the Nomination of Women Candidates', Electoral Studies 31(4), pp. 740-749. 
Vandeleene, A., De Winter, L., Meulewaeter, C. and Baudewyns, P. (2013) 'Candidate Selection: Explorations beyond the Secret Garden of Politics-The Case of Belgium'. Paper presented at the $12^{\text {th }}$ Dutch-Belgian Political Science Conference, 30-31 May.

Verleden, F. (2013) 'De Toegang tot de Parlementaire Elite: Politieke Rekrutering en Lijstvorming in België in Historisch Perspectief.' Paper Presented at the $12^{\text {th }}$ DutchBelgian Political Science Conference, 30-31 May.

Wauters, B., Weekers, K., and Pilet, J. (2004) 'Het Gebruik van de Voorkeurstem bij de Regionale en Europese Parlementsverkiezingen van 13 Juni 2004', Res Publica 46(2-3), pp. 377-412.

Young, L. (1994) Electoral Systems and Representative Legislatures: Consideration of Alternative Electoral Systems, Ottawa: Canadian Advisory Council on the Status of Women. 